Available online at: http://ejournal-balitbang.kkp.go.id/index.php/ifrj
e-mail:ifrj.puslitbangkan@ gmail.com
INDONESIAN FISHERIES RESEARCH JOURNAL
Volume 22 Number 1 June 2016
p-ISSN: 0853-8980
e-ISSN: 2502-6569
Accreditation Number: $704 /$ AU3/P2MI-LIPI/10/2015

\title{
MANGROVE OF BERAU: ECOLOGICAL CONDITION, FISHERIES, AND MANAGEMENT OPTIONS
}

\author{
Ivana Yuniarti ${ }^{\star 1}$, Triyanto', Nirmalasari Idha Wijaya², Fajar Sumi Lestari', Fajar Setiawan'and Sutrisno \\ ${ }^{1}$ Research Centre for Limnology, Indonesian Institute of Sciences, Jl. Raya Jakarta Bogor Km. 46 Cibinong Indonesia \\ ${ }^{2}$ East Kutai Academy of Agriculture, JI. Soekarno Hatta No 1 Sangatta, Kutai Kartanegara Indonesia \\ Received; Dec 07-2016 Received in revised from June 06-2016; Accepted June 09-2016
}

\begin{abstract}
Mangrove area of Berau District, East Kalimantan Province is an important buffering zone for Derawan Islands. It also becomes a distinctive habitat for commercial fisheries commodity. Land conversion into shrimp ponds has threatened its sustainability. This paper summarizing its ecological condition, fisheries, and management options presents a guideline for the decision makers about what strategies can be applied in conserving the mangrove sustainability. Overall, the ecological condition is proven to support sustainable fisheries practice; such as shrimp and crab silvofisheries. Moreover, the calculation of firewood economic value shows that a sustainable commercial firewood production is another option that can be established to support local economic activities. In addition, a well managing ecotourism may be considered by local government considering its potential for local economic growth.
\end{abstract}

\section{Keywords: Mangrove; fisheries; ecotourism; management; Berau}

\section{INTRODUCTION}

Mangrove area of Berau District, East Kalimantan Province extends for about 80,277 ha (Wiryawan et al., 2005). This area is recognized as the important buffering zone for Derawan Islands which become one of the jewels of marine tourism in Indonesia. Equally important, this area is also a remarkable habitat for some commercial fisheries commodity; for examples: prawns, mud crab (Scylla serrata) and flower/swing crab (Portunus pelagicus). Mud crab as one of the main commodities has fulfilled the demand of both local and international markets.

However, a serious threat from mangrove conversion into shrimp farms has emerged since 2007.According to the data published in Kompas.com (2003) the degraded area had accrued from 450 ha in 1997 to 4,000 ha in 2003. Considering this situation, a proper management should be planned and established in the very recent times. Thus, knowledge of the ecological condition, fisheries, and the possible development that sustains the resource should be largely known by the policy makers and also the stakeholders. Hence, this paper summarizing the recent ecological and fisheries condition is considered as one review that can be referred by the targeted stakeholders. Moreover, the possible fisheries management options are also reviewed in this paper to further help the decision makers to formulize a good management system.

\section{MATERIALS AND METHODS}

Ecological data were gathered from both direct ecological survey and secondary data from the work of Triyantoet al. (2012). Field surveys were conducted from April to July 2012 to assess the mangrove's litter production. In addition, other secondary data from Wiryawan et al. (2005) were also collected to complete the economic value data.

To estimate the litter production, several litter traps were set in 6 sites from May to July 2012 and July to October 2012 as a replication. The sites were Semantingluar, UlinganMuara, Batumbuk, Pisangpisang, Semantingdalam, and Birai (Figure 1). The litter samples were dried in $70^{\circ} \mathrm{C}$ and were 
weighted until the constant weight was obtained. The applied method was reffered to the work done by Zamroni \& Rohyani (2008).

A rapid rural assessment was applied to assess mangrove firewood function in Semanting Village in September 2012. To assess the economic value of firewood provision function of Semanting Village, a semi structured interview was undertaken on 31 households. For brief information, there are only 50 households inhabiting this village. Thereafter, the received information was analyzed with opportunity cost method and surrogate price method to generate the value following the work conducted by Gammage (1997).

Whilst, fisheries condition data including species composition, fishing effort, and annual production were collected from Department of Marine and Fisheries of Berau District.Moreover, data of fishing gears is also obtained from the rapid survey done in the surrounding villages.

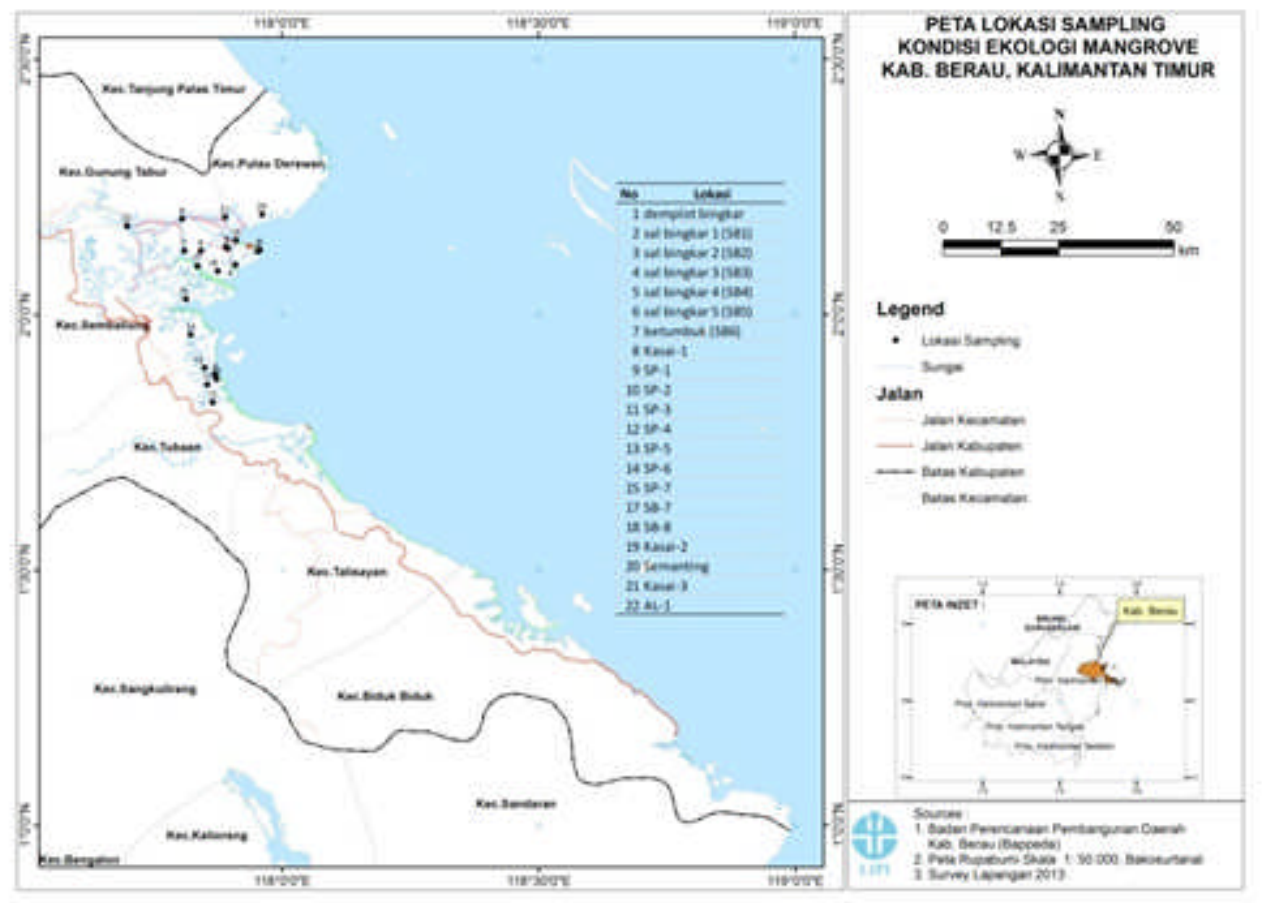

Figure 1. Sampling location map (Berau District's mangrove area).

\section{RESULTS AND DISCUSSION Results}

\section{Ecological Condition}

The survey on ecological condition of Berau District mangrove area covered three aspects. The first one is water quality of the mangrove waters (Appendix 1). The second aspect is the mangrove species and their indices of importance (Appendix 2), and the last one is its litter production to enhance its fisheries production (Table 1). Water quality condition and the species presented here are cited from the work of Triyanto et al. (2012). Meanwhile, the litter production data were collected from an ecological research in 2012. The data presenting the mangrove species and their indices of importance are presented in Appendix 2. Whereas data presented in Table 1 show the mangrove litter production.

\section{Fisheries}

Based on the statistical data issued by Department of Marine and Fisheries of Berau District (2010), several economically important fish species becoming the district's main fisheries commodities are mangrove dependent species. The species are indian halibut (Psettodeserumai), flat fish (Cynoglossus lingua), pony fish (Leiognatusequlus), sea catfish (Arius spp.), goat fish (Parupeneusspilurus), sweet lip fish, barramundi (Latescalcalifer), red snappers (Lutjanus sp.), great barracuda (Sphyraena barracuda), mullets (Mugilcephalus), scads (Carangoides spp.), groupers (Epinephelus spp.), trevallies (Caranx sp.), etc. Types of fishing gear recorded by Department of Marine and Fisheries of Berau District (2010-2012) are seine nets, purse seines, gillnets (drift, set, and trammel net), lift nets, hook and lines (i.e. troll line), traps (stow net, portable traps) and miscellaneous gears such as 
harpoon and shell fish collectors. In term of production gill nets (drift, set, and trammel net) are the most productive fishing gear. While traps (stow nets, trap and lines) is the second most productive gear and seine nets.

Table1. Berau District mangrove's litter production
Table 2 presents the production of crustaceans in Berau District from 2009 to 2011. The production of crustaceans was up to 2,113.9 in 2011 with the value reached for about IDR 62 billion (Department of Marine and Fisheries of Berau District).

\begin{tabular}{lcr}
\hline \multicolumn{1}{c}{ Site (s) } & $\begin{array}{c}\text { Litter production (gram dry weight/ } \\
\left.\mathbf{~ m}^{2} / \mathbf{d a y}\right)\end{array}$ & \multicolumn{2}{c}{$\begin{array}{c}\text { Litter production (MT dry } \\
\text { weight/ha/year) }\end{array}$} \\
\hline Semantingluar & 6.861 & 25.04 \\
UlinganMuara & 10.231 & 37.34 \\
Batumbuk & 2.833 & 9.85 \\
Pisangpisang & 0.458 & 1.67 \\
SemantingDalam & 3.970 & 14.49 \\
Birai & 1.174 & 4.29 \\
Average & 4.255 & 15.45 \\
\hline
\end{tabular}

Table 2. Production of crustaceans in Berau District from 2009 to 2011 (Department of Marine and Fisheries of Berau District, 2010-2012)

\begin{tabular}{rrrrrrrr}
\hline Year & $\begin{array}{l}\text { Swing crabs } \\
\text { (MT) }\end{array}$ & \multicolumn{1}{l}{$\begin{array}{l}\text { Mud crabs } \\
\text { (MT) }\end{array}$} & $\begin{array}{l}\text { Panuliridsoiny } \\
\text { lobsters (MT) }\end{array}$ & $\begin{array}{l}\text { Giant tiger } \\
\text { prawn (MT) }\end{array}$ & $\begin{array}{l}\text { Banana } \\
\text { prawn (MT) }\end{array}$ & $\begin{array}{l}\text { Metapeneus } \\
\text { shrimp (MT) }\end{array}$ & $\begin{array}{l}\text { Total } \\
\text { (MT) }\end{array}$ \\
\hline 2009 & 176 & 332.1 & 41 & 90.2 & 705.6 & 721.1 & 2066 \\
2010 & 170.3 & 326.3 & 46.3 & 95.3 & 710.7 & 729.4 & $2,078.3$ \\
2011 & 172.2 & 335.2 & 45.8 & 99.1 & 732.2 & 729.4 & $2,113.9$ \\
\hline
\end{tabular}

\section{Management Options}

The result of a rapid survey carried out in 2012 showed that the cumulativedirect value for 10 years generated by mangrove function as a firewood in
Semanting Village (one of fisher villages in Berau District) approaches IDR 135,301,826 The village itself covers about 206 ha of mangrove area (Setiawan, 2012). The value of firewood provision in this village is presented in Table 3.

Table 3. Present value of mangrove firewood provision function (10 years, $r=0.06$ )

\begin{tabular}{ccc}
\hline \multirow{2}{*}{ Year } & \multicolumn{2}{c}{ Present Value } \\
\cline { 2 - 3 } & Opportunity cost (IDR) & Surrogate price (gas) (IDR) \\
\hline 1 & $11,982,076$ & $19,606,552$ \\
2 & $11,303,845$ & $16,046,960$ \\
3 & $10,664,005$ & $15,138,642$ \\
4 & $10,060,382$ & $14,281,737$ \\
5 & $9,490,927$ & $13,473,337$ \\
6 & $8,953,704$ & $12,710,695$ \\
7 & $8,446,891$ & $11,991,222$ \\
8 & $7,968,765$ & $11,312,474$ \\
9 & $7,517,703$ & $10,672,145$ \\
10 & $7,092,172$ & $10,068,061$ \\
\hline Value & $93,480,471$ & $135,301,826$ \\
\hline
\end{tabular}




\section{Discussion}

Overall, Triyanto et al. (2012) concluded that the mangrove's water quality was still appropriate to support the life of mud crab. The conclusion was noticed based on the $\mathrm{pH}$, temperature, salinity, dissolved oxygen (DO), Total Nitrogen (TN) and Total Phosphorous (TP) level from a survey in 2012 which were categorized in the range of living requirement for various crustaceans (Triyantoet al., 2012).

The data in Appendix 2 show that there were 24 identified species in this mangrove area. In general, there is no single species occupying whole area. The dominant species variedwithin sampling areas. The genera Avicenniadominated the beach area such as UlinganPantai and Talisayan. On the other hand, the genus Pongamia was prominent in Sulaiman Bay and Giring-giring. At the same time generaSonneratiawas abundant in Semanting and Kalendakan and the other sites were occupied mostly by other genera; for instances: Ceriopsand Nypa.

With the extent of BerauDisctrict's mangrove area approaching 80,277 ha, the litter production of the mangrove is estimated about 1,348,217 MT dry weight/year or similar to $15.45 \mathrm{MT}$ dry weight/ha/year. This production is considered moderately higher than the litter production of TelukSepi Mangrove in West Lombok Indonesia. A research done by Zamroni\&Rohyani (2008) revealed that the litter production of the region was $9.9 \mathrm{MT}$ dry weight per ha per year. Furthermore, the research done by Wibisana (2004) found that litter production of only Rhizophora and Avicennia in Berau District Coastal area approached $5.41 \mathrm{MT} / \mathrm{ha} /$ year. It proves that Berau District's mangrove area has higher potential fisheries productivity than the mangroves of Lombok. Moreover, the observation of litter production was accomplished in moderately and severely long dry season. If the research was extended to rainy season the litter production might increase significantly. According to Soeroyo (2003) litter production is highly influenced by rainfall.

The value of calculated chlorophyll-a is considered low in all sampling sites. This condition shows low productivity of phytoplankton organism in this region. In contrast, litter production outlined in Table 1 shows high potential fisheries productivity. It can be presumed that litter food chain is more dominant in this mangrove area. Thus, the mangrove is appropriate to be managed as a habitat site for the organisms utilizing the detritus as their main food (i.e. crabs and shrimps). In addition, the water quality data also supports for the development of crustacean fisheries.
The fish species identified in the mangrove area use the ecosystem as their nursery and spawning ground (Nagelkerken, 2008). In addition, some crustaceans are also captured in the mangrove area such as Swing crabs, mud crabs (Scylla spp.), Soiny lobsters, Giant tiger prawn, Banana prawn, and Metapeneus shrimps (Department of Marine and Fisheries of Berau District, 2010-2012).

In term of production and value, Banana prawn shares the biggest part among all other crustaceans production. Meanwhile, Banana prawns and Mud crabs placed in the second and third rank for production. At the same manner, Metapeneus shrimps and Panulirid spiny lobsters ranked the second and third place in term of their values. It can also be seen from Table 2 that mud crabs as the main commodity actually only shares about $16 \%$ of the district's total crustacean productions. However, the crab production in this district is only done by capturing activities. On the other hand, prawn and shrimp production data are obtained from both capture and culture production. Thus, the expansion of crab production is still largely possible to be done by introducing sustainable crab culture techniques. The culture can be operated in degraded mangrove areas such as the abandoned shrimp ponds. In contrast, the conventional way to expand prawn and shrimp production is becoming more limited due to the degradation of mangrove habitat in the area.

Considering its potential economic value, which approaches US\$1,395.50/ha/year (Wiryawanet al., 2005), the development of the area should be wisely considered by the decision maker parties. As a comparison the value of mangrove firewood provision in Thailand approached US \$30 per ha in 1979 or about IDR 82,500 cited in 1979 currency (FAO, 1979 cited in Christensen (1983). In addition, Emerton et al. (2003) cited in IUCN (2007) found that this value was about US\$82.917 in 2003 currency.

Mangrove wood utilization specifically genera Rhizophora is very popular in many countries such as India and Bangladesh. Firewood has been commercially marketed in large quota in these countries (Christensen, 1983). Nevertheless, in Berau District there is no indication that commercial trading for firewood has existed. This condition is very suitable for enhancing conservation effort; on the other hand, it is less beneficial for small scale economic development. If a regulation about restricted mangrove firewood trading (i.e. only branches, twigs, and old trees that have been rehabilitated to be traded) can be established, a good economic development can be augmented and it also against the increment of 
illegal logging. A good commercial firewood trade can be regarded as a valuable resource to enhance economic activities; for example in Sierra Leone. It is stated by Munro et al. (2011) that trade of firewood together with timber has become significantly important economic materials in the country.

Considering its high detritus production and suitable water quality level for the life of crustaceans, the development of crustacean fisheries sector such as crabs and shrimps is a great opportunity that can be optimized. In the past, fisheries sector which actually could empower the economic sector of the district had caused serious threats for the sustainability of mangrove ecosystem. Other alternatives have to be applied and evaluated to increase fisheries production as well as to sustain conservation efforts. Some options that can be considered are shrimp and crab silvofishery technique. Several options suggested to obtain these purposes are given in Table 4.

Table 4. Options for mangrove management action

\begin{tabular}{|c|c|c|}
\hline Management action & Site (s) & Reference (s) \\
\hline Silvofishery & $\begin{array}{l}\text { Tugurejo Semarang (Indonesia); } \\
\text { Bang La Commune (Vietnam) }\end{array}$ & Diartoet al. (2012); Datet al. (2013) \\
\hline Eco-tourism & Can Gio (Vietnam) & Datet al. (2013) \\
\hline $\begin{array}{l}\text { Sustainable fuelwood } \\
\text { production }\end{array}$ & The Sierra Leone & Munro et al.(2011) \\
\hline Mangrove protection belt & Mekong Delta (Vietnam) & $\begin{array}{l}\text { Benthemet al. (1999) in Streever } \\
\text { (ed. ) (1999) }\end{array}$ \\
\hline $\begin{array}{l}\text { Comunity based mangrove } \\
\text { management }\end{array}$ & Thailand, Phillipines & $\begin{array}{l}\text { Sudtongkonget al. (2008) and } \\
\text { Primavera et al. (2008) cited in } \\
\text { Dattaet ai. (2012) }\end{array}$ \\
\hline $\begin{array}{l}\text { Integrated shrimp, crab, } \\
\text { blood cockle culture }\end{array}$ & Ca Mau (Vietnam) & Minh et al. (2001) \\
\hline $\begin{array}{l}\text { Rehabilitation of } \\
\text { abandoned shrimp farms }\end{array}$ & Vietnam & $\begin{array}{l}\text { Stevenson et al. (1999) in Streever } \\
\text { (ed. ) (1999) }\end{array}$ \\
\hline
\end{tabular}

The table presents several possible options for managing Berau District's mangrove area. Ecotourism in particular is a good option to be implemented in District of Berau's mangrove area since it generates both economic and conservation value. Large mangrove area, species richness, and its valuable connection to Derawan Islands may be the main attracting factors for tourists to visit the area; therefore, it is possibe to gain popularity among both domestic and international tourists.

The tourismitself is mostly linked to local employment creation, sustainable development, and economic development particularly in developing countries (Campbell, 2002 in Jones, 2005). More importantly ecotourism gives direct financial benefits to local community and has minimize (low) impacts to the environment compares to the 'traditional' tourism (Foucat, 2002). However, ecotourism may have some criticizes such as that only few cases are proven to be sustainable (Foucat, 2002). Furthermore, the author described that the main challenges with the co-managed ecotourism are impact minimisation, benefit sharing equity, and integration of national policy. Thereafter, Jones (2005) presented that it can only provide maximum benefits for local communities if only the local communities have significant parts of control and benefit sharing. Thus, to engage local community in high level control and participation, ecotourism should be a community based initiative program.

In present, this tourism system is developed in a neighboring district, Tarakan. Referring to the work of Wiharyanto (2007), mangrove area in Tangkayu II port conservation area Tarakan is capable of supporting for about 1,800 visiting hours each day. Meanwhile, the more established and famous mangrove ecotourism taken place in Surabaya and Bali.

\section{CONCLUSION}

Based on the ecological condition, mangrove area of Berau District is very potential to enhance fisheries sector. The proposed option for the development of this sector is by engaging sustainable fisheries practice such as silvofishery in the rehabilitated degraded area. Moreover, to generate anadditional direct economic value, sustainablefirewood business is another managementoption that can be applied. This activity has been proven to generate significant 
economic value if it is sustainably practiced. In addition, a sustainable ecotourism operated by local people may be developed to facilitate sustainable economic development in the area.

\section{REFERENCES}

Benthem, W., van Levieren, L.P., \& Verheugt, W.J.M. (1999). Mangrove rehabilitation in the Coastal Mekong Delta Vietnam. In Streever,W.(ed). An international perspective on wetland rehabilitation (pp. 29-36). Netherland: Kluwer Academic Publisher.

Christensen, B. (1983). Mangroves what are they worth?. Journal of Forestry and forest industries 35.

Dat, P.T., \& Yoshino, K. (2013). Comparing mangrove forest management in Hai Phong City, Vietnam towards sustainable aquaculture. Procedia Env. Sci J 17, 109-118.

Datta, D., Chattopadhyay, R.N., \& Guha, P. (2012). Community based mangrove management: $A$ review on status and sustainability. Env Management J. 107, 84-95.

Foucat Avila V.S. (2002). Community-based ecotourism management moving towards sustainability, in Ventanilla,Oaxaca, Mexico. Ocean \& Coastal Management J. 45, 511-529.

Gammage, S. (1997). Estimating the returns to mangrove conversion: sustainable management or short term gain? (pp.1-56). Discussion paper of Environmental Economics Programme.

Jones, S. 2005. Community-Based Ecotourism The Significance of Social Capital. Annals of Tourism Research J. 32.(2), 303-324.

Kompas.com. (2011, August 28). 4.000 Hektar Hutan Mangrove Delta Berau Habis Dibabat $(4,000$ ha mangrove areas of Berau Estuary are deforestated). Retrieved from http://www.kompas.com/kompascetak/0310/21/daerah/636741.html.

Minh,T.H., Yakupitiyage, A., \& Macintosh, D.J. (2001). Management of the Integrated Mangrove-
Aquaculture Farming Systems in the Mekong Delta of Vietnam: 24. In ITCZM Monograph 1. Thailand.

Munro, P., \& Hiemstra-van der Horst, G. (2011). The domestic trade in timber and fuelwood products in Sierra Leone: current dynamics and issues (pp. 3-95). 2001 Research Report. Retrieved from http:/ /www.energyforopportunity.org/site_media/media/ files / d ocuments/final_report __fuelwood_and_timber_trade_in_sierra_leone.pdf

Nagelkerken, I., Blaber, S.J.M., Bouillon, S., Green, P., Haywood, M., Kirton, L.G., Meynecke, J-O., Pawlik, J., Penrose, H.M., Sasekumar A., \& Somerfield, P.J. (2008). The habitat function of mangroves for terrestrial and marine fauna: A review. Aquatic Botany J. 89, 155-185.

Soeroyo. (2003) (in Indonesian). Mangrove litter observation in Sembilang. South Sumatra) (p. 3844). 2003 Research Report.

Stevenson, N.J., Lewis, R.R., \& Burbridge, P.R. (1999). Disused shrimp ponds and mangrove rehabilitation in Streever, W.(ed). An international perspective on wetland rehabilitation (p. 277-297). Netherland: Kluwer Academic Publisher.

Wibisana, B.T. (2004) (in Indonesian). Mangrove Litter Production and Decomposision in Berau District's Coastal Area. Master Thesis. Bogor Agricultural University.

Wiharyanto, D. (2007) (in Indonesian). A study of Mangrove Ecotourism Development in Tengkayu Port, Tarakan, East Kalimantan. Master Thesis. Bogor Agricultural University.

Wiryawan, B., Khazali, M., \& Knight, M., (eds.). 2005 (in Indonesian). Toward Berau's Conservation Area: Coastal Resousce Status and The Development Proccess. 20005 Research Project. Retrieved from https://perikananberau.files.wordpress.com/2010/ 05/buku_menuju-kkl-berau.pdf

Zamroni, Y., \& Rohyani, I.S.I.S. (2008) (in Indonesian). Mangrove's litter production in coastal waters of Sepi Bay, Western Lombok. Biodiversitas. 9 (4), 284-287. 